\title{
Utilisation of Nitrogen by the Grape-vine as Affected by Time of Application and Soil Type
}

\author{
W.J. Conradie* \\ Viticultural and Oenological Research Institute, Private Bag X5026, 7600 Stellenbosch, Republic of South Africa.
}

Submitted for publication: May 1986

Accepted for publication: August 1986

Keywords: Nitrogen, Grape-vine, Nutrition

\begin{abstract}
Two-year-old Chenin blanc vines in sand culture were nurtured with ${ }^{15} \mathrm{~N}$-labelled nutrient solution at three different phenological stages, i.e. (1) between end of bloom and end of rapid shoot growth (spring), (2) between the end of rapid shoot growth and véraison (summer) and (3) post-harvest (autumn). The fate of the applied ${ }^{15} \mathrm{~N}$ was followed quantitatively over one year. In the spring and summer treatments, $43 \%$ of the labelled $N$ was translocated to the bunches while only $22 \%$ was still present as $N$ reserves at the start of the next season. In the autumn treatment, however, $68 \%$ of the labelled $\mathbf{N}$ was still present as reserves at the start of the next season. For the spring and summer treatments, migration of $\mathbf{N}$ from the leaves prior to leaf-fall and from the shoots prior to pruning, accounted for about $60 \%$ of the $\mathbf{N}$ reserves present at the start of the next season. Labelled $\mathbf{N}$ was also applied in the field during spring and autumn, using vines on sandy loam $(20 \%$ clay) and sandy ( $8 \%$ clay) soils as test material. In the sandy loam soil about $30 \%$ of the labelled $\mathbf{N}$ from both the spring and autumn treatments was utilised by the vine up to the end of bloom in the following season. In the sandy soil about $50 \%$ of the labelled $\mathbf{N}$ was utilised by the vine during the same period. It is suggested that the higher utilisation of $\mathbf{N}$ on the sandy soil could be due to a lower content of organic matter. Less mineral $\mathbf{N}$ in the root zone of the sandy soil may cause a smaller dilution of applied $\mathrm{N}$, giving rise to a larger fraction of applied $\mathbf{N}$ being utilised.
\end{abstract}

In a recent review it was pointed out that a vast amount of information exists on the production, transport and utilisation of photosynthetically fixed carbon in plants (Pate, 1980), but in contrast to this the present situation regarding knowledge about the nitrogen $(\mathrm{N})$ relationships of plants, is totally inadequate. In the case of the grape-vine, lack of this information has prevented the establishment of an acceptable basis for fertilisation recommendations even though workable guidelines have been suggested for South Africa (Saayman, 1981).

Developing fruit accumulate large quantities of $\mathrm{N}$ (Stassen, Du Preez \& Stadler, 1983) and in the case of the grape-vine it has been suggested (Conradie, 1983) that a large fraction of this is derived from previously assimilated $\mathrm{N}$. In the case of perennial plants, pools of reserve $\mathrm{N}$ are therefore especially important with respect to growth and development during the following season, and it is known that the demand for $\mathrm{N}$ exceeds the absorption capacity of the roots during the early part of the season (Conradie, 1980; Legaz \& Millo, 1981; Stassen, Terblanche \& Strydom, 1981b; Stassen, Du Preez \& Stadler, 1983). However, most of the investigations done up to now have been carried out with conventional methods whereby it is impossible to distinguish between currently absorbed and reserve N. In the case of the grape-vine the relative importance of pools of reserve $\mathrm{N}$ accumulated at different times of the season, has therefore not yet been determined. The development of techniques using ${ }^{15} \mathrm{~N}$ enriched fertilisers, has now made it possible to do studies of this nature. It is also known that, in the case of deciduous fruit, a large portion of the leaf- $\mathrm{N}$ migrates back to the permanent structure of the tree prior to leaf-fall (Titus \& Kang, 1982). This amount of $\mathrm{N}$ can constitute up to $50 \%$ of the total amount of $\mathrm{N}$ present in the leaves
(Taylor \& Van den Ende, 1969; Titus \& Kang, 1982) and makes a substantial contribution to the $\mathrm{N}$ reserves. However, as far as known, the relative importance of pools of $\mathrm{N}$ accumulated at different phenological stages, has never been determined for deciduous fruit.

Apart from the aspects concerning the utilisation of $\mathrm{N}$ which have been mentioned and which need further research, the question whether the organic matter (OM) content of soils should be taken into account when making fertilisation recommendations, remains largely unanswered. In most soils more than $90 \%$ of the total amount of $\mathrm{N}$ is bound in the organic form and, depending on different factors, between $1 \%$ and $3 \%$ may be mineralised each year (Amberger, 1983). The mineral $\mathrm{N}$ (mainly nitrate $\mathrm{N}$ ) present at the beginning of the growing season should be taken into account in calculating the fertiliser demand. This approach is generally known as the $\mathbf{N}_{\min }$-method (Wehrmann et al., 1982) and has been used with success for annual crops. Lately this approach has also been advocated for deciduous trees (Scharpf \& Wehrmann, 1979) and the grape-vine (Müller, 1982). However, the $\mathbf{N}_{\min }$-method requires all vineyard soils to be analysed for mineral $\mathrm{N}$ at the beginning of the growing season. These analyses will have to be completed within a space of two weeks which is, at present, not feasible in South Africa. An alternative approach is to classify soils according to their mineralisation capacity which is normally correlated with OM content of the soil. This relatively easy approach which has been sucessfully applied by the sugar industry of South Africa (Meyer et al., 1983) entails the chemical determination of the OM content of the soil which does not change as quickly as the mineral $\mathrm{N}$ content. In the case of the grape-vine grown under South African conditions, Saayman (1981) argued that if prunings and

${ }^{*}$ Extract from a Ph.D. (Agric.) thesis presented to the University of Stellenbosch, March 1986. Promotor: Prof A.A. Theron.

Acknowledgement: The author wishes to thank Messrs P.J.E. Louw and A. Fourie for technical assistance.

S. Afr. J. Enol. Vitic., Vol. 7 No. 21986 
grape skins are returned to the soil and if this is combined with a good stand of cover crop, existing OM contents of soils should be maintained. However, the OM level at which the addition of $\mathrm{N}$ fertilisers becomes unnecessary, has never been investigated

A final aspect of $\mathrm{N}$ utilisation which has received scant attention in South Africa, is leaching. As the soils on which grape-vines are cultivated may vary from very sandy ( $<1 \%$ clay) to heavy ( $>30 \%$ clay), the extent to which leaching will occur can also be expected to differ markedly. Ideally all the applied fertiliser should be taken up at the end of the growing season in order to minimise the possibility of leaching during winter (Amberger, 1983). This aspect can also be investigated by means of ${ }^{15} \mathrm{~N}$ enriched fertilisers.

In this study the ${ }^{15} \mathrm{~N}$ isotope was used in order to determine the utilisation of $\mathrm{N}$ absorbed by the grape-vine at different growth stages and in different growth media. It was possible to follow the translocation of $\mathrm{N}$, which had been absorbed during the different phenological stages, quantitatively.

\section{MATERIALS AND METHODS}

\section{Experiment 1:}

Two-year-old Vitis vinifera L. cv. Chenin blanc vines grafted on 99 Richter rootstock were used in this study. The vines were grown in sand culture with a standard Hoagland solution as described by Conradie (1980). Thirty-two vines were labelled with ${ }^{15} \mathrm{~N}$ from the end of bloom (11th November) to the end of rapid shoot growth (18th December, when shoot growth decreased to less than $25 \mathrm{~mm}$ per week) by replacing part of the standard $\mathrm{KNO}_{3}$ in Hoagland's solution with labelled $\mathrm{KNO}_{3}$ to give a nutrient solution containing 9,87 atom $\%$ excess ${ }^{15} \mathrm{~N}$. At the end of the labelling period excess ${ }^{15} \mathrm{~N}$ was leached from the sand and the plants received the standard Hoagland solution for the rest of the investigation period. The fate of this ${ }^{15} \mathrm{~N}$, designated as "spring N", was followed for roughly one year. To accomplish this, four whole vines were sampled at each of the following eight phenological stages : end of rapid shoot growth, véraison, harvest, start of leaf-fall, end of leaf-fall, budbreak, before bloom and two weeks after the end of bloom. The different organs of the vines were quantitatively separated, i.e. rootstock trunk, scion trunk and cordons, medium roots (diameter $>$ $2 \mathrm{~mm}$ ), fine roots (diameter $<2 \mathrm{~mm}$ ), shoots (current growth), leaf-blades, petioles and bunches. All samples were analysed for total $\mathrm{N}$ as described previously (Conradie, 1980). Atom \% excess ${ }^{15} \mathrm{~N}$ was also determined for all tissues as described by Conradie (1983) and this made it possible to calculate the absolute amount of fertiliser N ("spring N") present in each group of organs at each of the sampling dates.

\section{Experiment 2:}

The vines used in this investigation were of the same cultivar and age as those in Experiment 1. Twenty-eight vines were labelled with ${ }^{15} \mathrm{~N}$ in a similar way but in this case the labelling was done between the end of rapid shoot growth and véraison. This gave rise to a pool of labelled $\mathrm{N}$ designated as "summer N". Vines were sampled during the latter seven phenological stages mentioned for Experiment 1 and analysed similarly.

\section{Experiment 3:}

In this experiment fifteen vines were labelled with ${ }^{15} \mathrm{~N}$ during the first month after harvest, which gave rise to a pool of labelled $\mathrm{N}$ designated as "autumn $\mathrm{N}$ ". Three vines were sampled during each of the last five phenological stages mentioned for Experiment 1 and analysed similarly.

\section{Experiment 4:}

This investigation was carried out in a 15 -year-old Chenin blanc/Jacquez vineyard with a planting distance of $3,0 \mathrm{~m} \times 1,5 \mathrm{~m}$. The soil was of the Glenrosa form (Macvicar et al., 1977) developed on shale, with an average clay content of $20 \%$ in the $0-600 \mathrm{~mm}$ layer, where most of the roots were found. The vines had not been fertilised previously and yielded on average, $3,5 \mathrm{~kg}$ grapes per vine. The OM content of the $0-600 \mathrm{~mm}$ layer was $0,84 \%$ (Walkley-Black method, using a factor of 1,7 to convert from carbon to OM). Three vines were labelled with $100 \mathrm{mg}{ }^{15} \mathrm{~N}$ in spring (7th October), and another three in autumn (10th March), using the same concentration. To accomplish this $702 \mathrm{mg}$ of ${ }^{15} \mathrm{~N}$ enriched $\mathrm{KNO}_{3}\left(97\right.$ atom \% excess $\left.{ }^{15} \mathrm{~N}\right)$ was dissolved in 1 litre of water and for each vine this amount was applied concentrically, within a radius of $600 \mathrm{~mm}$, to the soil around the vine. In the case of the spring application, $18 \mathrm{~mm}$ of rain fell on the day following application while $20 \mathrm{~mm}$ irrigation water was applied on the second day after the autumn application. In both cases a control vine was treated similarly with unlabelled $\mathrm{KNO}_{3}$. In the case of the spring application, leaves were sampled two weeks after the end of bloom and again at harvest while bunches were sampled at harvest and total yield determined. From this point onwards vines from both treatments were sampled on the same dates. During leaf-fall a composite leaf sample was collected while the total number of leaves per vine was determined. Vines were pruned at the end of June, the prunings weighed and a sample taken for analysis. Leaves were again sampled at the end of bloom in the next growing season while all leaves present were counted. Bunches were sampled when the berries were about $5 \mathrm{~mm}$ in diameter, while all bunches were also counted. All samples were dried, weighed and analysed for total $\mathrm{N}$ as well as for atom \% excess ${ }^{15} \mathrm{~N}$ as described previously (Conradie, 1983). Rye was sown as a winter cover crop, and killed with a herbicide just prior to budbreak. During summer, the vines received two sprinkler irrigations of about $60 \mathrm{~mm}$ each.

\section{Experiment 5:}

This investigation was carried out in a six-year-old Bukettraube/Ramsey vineyard with a planting distance of 2,4 $\mathrm{m} \times 1,0 \mathrm{~m}$. The soil was of the duplex Kroonstad form (Macvicar et al., 1977) and contained about $8 \%$ clay in the 0-600 mm layer. The vines had not been fertilised previously and yielded about $4,7 \mathrm{~kg}$ grapes per vine. A fluctuating water table occurred at $600 \mathrm{~mm}$ resulting in very few roots occurring below this depth. The average OM content of the topsoil amounted to $0,38 \%$.

Viticultural practices were indentical to those followed for Experiment 4, and vines were labelled with ${ }^{15} \mathrm{~N}$ on the same dates. However, due to the closer spac- 
TABLE 1

Distribution of the total amount of nitrogen and dry material accumulated annually by Chenin blanc/99 Richter.

\begin{tabular}{|c|c|c|c|c|}
\hline Organ & (mg/vine \pm S.E. $)$ & (\% of total) & (g/vine) & (\% of total) \\
\hline $\begin{array}{l}\text { Bunches (at harvest) } \\
\text { Leaves (at end of leaf-fall) } \\
\text { One-year-old shoots (at pruning) } \\
\text { Permanent parts (at budbreak) } \\
\text { Total }\end{array}$ & $\begin{array}{l}3253 \pm 260 \\
2058 \pm 230 \\
1277 \pm 160 \\
2601 \pm 190 \\
9189\end{array}$ & $\begin{array}{r}35,4 \\
22,4 \\
13,9 \\
28,3 \\
100\end{array}$ & $\begin{array}{l}485 \\
141 \\
140 \\
215 \\
981\end{array}$ & $\begin{array}{r}49,4 \\
14,4 \\
14,3 \\
21,9 \\
100\end{array}$ \\
\hline
\end{tabular}

ing, ${ }^{15} \mathrm{~N}$ was applied within a circle of $450 \mathrm{~mm}$ around each vine.

\section{RESULTS AND DISCUSSION}

The annual distribution of $\mathrm{N}$ and dry material between the different organs (average of Experiments 1,2 and 3 ) of the grape-vine is shown in Table 1 . As was found in a previous experiment (Conradie, 1980), at harvest the bunches contained more than a third of the amount of $\mathrm{N}$ absorbed annually. Approximately a quarter $(28,3 \%)$ of the total amount of $\mathrm{N}$ absorbed over the course of one season was still available as reserves at the start of the next season. Accumulation of dry material appeared to be largely independent from $\mathrm{N}$ allocation, as evidenced by the fact that the distribution of $\mathrm{N}$ between the various organs differed from that found for dry material.

The amount of $\mathrm{N}$ absorbed annually by the grapevine (average of Experiments 1, 2 en 3), during five distinct phenological stages, as well as the $\mathrm{N}$ demand of the new growth, is shown in Table 2.

About one fifth of the vine's annual demand for $\mathrm{N}$ was absorbed between budbreak and the end of bloom (first stage). During this period the new growth in all three Experiments showed a demand for $\mathrm{N}$ which was larger than the amount of $\mathrm{N}$ absorbed by the roots. On average this "deficit", which was satisfied by an efflux of $\mathrm{N}$ from the roots and permanent wood, amounted to $20,4 \%$ of the total demand (1 $948 \mathrm{mg}$ per vine) during this period. This fact stresses the importance of reserve $\mathrm{N}$ during this period because the roots are obviously not capable of satisfying the vine's demand for $\mathrm{N}$ even if, as in this case, enough $\mathrm{N}$ is available in the root zone. Similar indications were found previously (Alexander, 1957; Kliewer, 1967; Schaefer, 1981) for the grape-vine but, as far as known, the only quantitative estimate was previously done by Conradie (1980) in which case the "deficit" during this period amounted to $30 \%$.
During the end of bloom to the end of rapid shoot growth stage, the rate of $\mathrm{N}$ absorption increased from $195 \mathrm{mg}$ to $226 \mathrm{mg}$ per vine per week. As was previously found (Conradie, 1980), the $\mathrm{N}$ demand of the new growth during this stage was almost similar to the root uptake of $\mathrm{N}$, resulting in $\mathrm{N}$ reserves being of less importance. The reproductive organs (bunches) utilised $56 \%$ of the $\mathrm{N}$ absorbed during this period. The fastest rate of $\mathrm{N}$ uptake occurred during the next stage (end of rapid shoot growth to véraison), possibly on account of the large requirement of the bunches which accumulated $1100 \mathrm{mg}$ of $\mathrm{N}$ per vine, i.e. more than $60 \%$ of the $\mathrm{N}$ absorbed during this period. However, $\mathrm{N}$ uptake by the roots was nearly sufficient to satisfy the vine's demand for "new N" during this period.

From veraison to harvest the rate of $\mathrm{N}$ uptake decreased slightly, with the bunches again being the largest sink for newly absorbed $\mathrm{N}$, requiring $1330 \mathrm{mg}$ of $\mathrm{N}$ per vine, i.e. about $73 \%$ of the $\mathrm{N}$ absorbed during this period. It is known that the uptake of $\mathrm{N}$ by the grapevine decreases or stops completely when grapes reach maturity (Lafon et al., 1965; Conradie, 1980). The rate of $\mathrm{N}$ uptake was therefore probably much slower just prior to harvest than immediately after véraison.

Uptake of $\mathrm{N}$ during the post harvest stage (27\%) generally occurred at a relatively high rate up to the start of leaf-fall. However, in some cases, (Experiment 1) about $50 \%$ of the total post harvest uptake occurred during leaf-fall. In practice, therefore, leaves should be retained as long as possible in order to enhance the $\mathrm{N}$ status of the grape-vine. This is in agreement with the results of Weinbaum et al. (1978) who found that the nitrate uptake efficiency of prune trees decreased rapidly during natural leaf-fall.

The annual utilisation of ${ }^{15} \mathrm{~N}$ pools which were absorbed by the grape-vine at the three distinct phenological stages (Experiments 1, 2 and 3) is shown in Figure 1. The fate of $\mathrm{N}$ accumulated either in spring or in early summer was remarkably similar. In both cases about

TABLE 2

Amount and rate of nitrogen absorbtion by Chenin blanc/99 Richter vines during different phenological stages ${ }^{(a)}$.

\begin{tabular}{|c|c|c|c|c|}
\hline Phenological stage & $\begin{array}{c}\text { Amoun } \\
(\mathrm{mg} / \text { vine } \pm \text { S.E })\end{array}$ & $\begin{array}{l}\text { orbed } \\
(\% \text { of total) }\end{array}$ & $\begin{array}{l}\text { Absorb. rate } \\
(\mathrm{mg} \text { per week) }\end{array}$ & $\begin{array}{l}\text { N-demand of new } \\
\text { growth (mg/vine) }\end{array}$ \\
\hline $\begin{array}{l}\text { Budbreak to end of bloom } \\
\text { End of bloom to end of } \\
\text { rapid shoot growth }{ }^{(\mathrm{b})} \\
\text { End of rapid shoot growth } \\
\text { to véraison } \\
\text { Véraison to harvest } \\
\text { Post harvest } \\
\text { Total }\end{array}$ & $\begin{array}{l}1948 \pm 180 \\
1130 \pm 120 \\
1801 \pm 150 \\
1829 \pm 190 \\
2481 \pm 290 \\
9189 \pm 890\end{array}$ & $\begin{array}{r}21,2 \\
12,3 \\
19,6 \\
19,9 \\
27,0 \\
100,0\end{array}$ & $\begin{array}{l}195 \\
226 \\
450 \\
366 \\
138 \\
219\end{array}$ & $\begin{array}{l}+2446 \\
+1115 \\
+1698 \\
+2008 \\
-\quad 784 \\
+6483\end{array}$ \\
\hline
\end{tabular}

(a) The indicated phenological stages, following budbreak at 30th August, lasted 10, 5, 4, 5 and 18 weeks sequentially.

(b) End of rapid shoot growth occurred about middle December when the rate of shoot growth decreased to less than $25 \mathrm{~mm}$ per week. 
DBunches (at harvest) Shoots (at pruning) 用的unaccounted
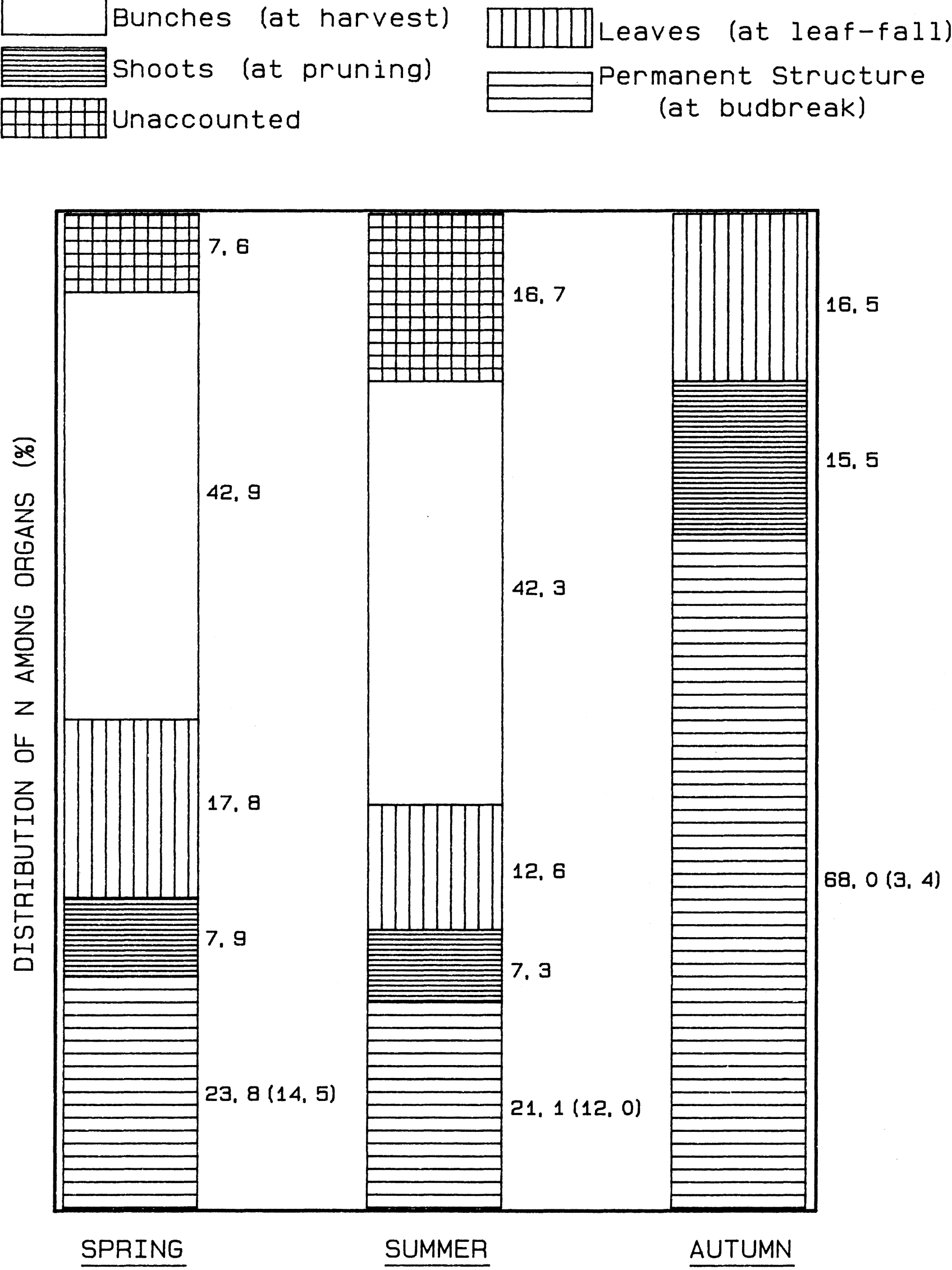

FIG. 1.

Distribution of $\mathrm{N}$ among vine organs as affected by time of application. Value in parenthesis indicates the fraction (\%), present in the permanent structure, due to migration from leaves and shoots. 
$43 \%$ was removed through harvest while $21 \%$ to $24 \%$ was present as reserve $\mathrm{N}$ at the start of the next season. In the case of "spring $N$ " the leaves contained a larger fraction of the labelled $\mathrm{N}$, possibly on account of the leaves being a relatively stronger sink for $\mathrm{N}$ during the early part of the season. The only other significant difference between the two pools was the fact that a much larger fraction $(16,7 \%)$ of labelled $\mathrm{N}$ was unaccounted for in the case of "summer $N$ " than for "spring $N$ " $(7,6 \%)$. In the latter case the small loss may be attributed to the constant renewal processes of roots but in the case of "summer N" extra losses must have occurred. This could mean that $\mathrm{N}$ which was absorbed later in the season, is more prone to losses on account of root exudates or gaseous losses by the leaves and shoots (Hill-Cottingham \& Lloyd-Jones, 1975; Yoneyama, 1983).

Even though ${ }^{15} \mathrm{~N}$ was not applied between véraison and harvest, $\mathrm{N}$ absorbed during the later parts of the season is known to be more readily translocated to the crop in the form of amino acids (soluble $\mathrm{N}$ ), than being incorporated in proteins, compared to $\mathrm{N}$ absorbed earlier in the season (Yoneyama, 1983). Conradie (1986) showed that grapes from the "summer N" treatment had a higher concentration of soluble $\mathrm{N}$ than grapes from the "spring N" treatment. It is known that an excessive supply of $\mathrm{N}$ may cause bunch rot (Marocke et al., 1977), and if it is assumed that bunch rot is enhanced more by the soluble $\mathrm{N}$ fraction than by the protein $\mathrm{N}$ fraction, an over-supply of $\mathrm{N}$ will be more detrimental to grape quality if applied during the later part of the season than when applied during the earlier part.

In the case of labelled $\mathrm{N}$ absorbed during the post harvest period (Fig. 1), the largest fraction (68\%) remained in the permanent structure. Nitrogen reserves accumulated during the post harvest period, therefore, had a more pronounced effect on sustaining new growth during the following season than was the case for "spring $\mathrm{N}$ " and "summer N". It was found that about half of the $\mathrm{N}$ reserves present at budbreak are utilised up to harvest (Conradie, 1986). Accordingly it would mean that $12 \%$ and $10 \%$ of the $\mathrm{N}$ absorbed during "spring" and "summer" will be utilised during the next season as against $34 \%$ for post harvest $\mathrm{N}$. The importance of a sufficient amount of $\mathrm{N}$ in the root-zone during the post harvest period is therefore evident.

The percentage of labelled $\mathrm{N}$ which migrated back from the leaves to the permanent structure of the vine before leaf-fall and the amount of labelled $\mathrm{N}$ which migrated back from the shoots before pruning, are shown in Table 3.

TABLE 3

Migration of ${ }^{15} \mathrm{~N}$ from leaves prior to leaf-fall and from the shoots prior to pruning, for ${ }^{15} \mathrm{~N}$ absorbed at three different phenological stages.

\begin{tabular}{|c|c|c|c|}
\hline \multirow[b]{2}{*}{$\begin{array}{l}\text { Phenological stage } \\
\text { when }{ }^{15} \mathrm{~N} \text { was } \\
\text { supplied }\end{array}$} & Leaves & Shoots & \multirow[b]{2}{*}{$\begin{array}{l}\text { Migrated } \mathrm{N} \text { as } \\
\text { a fraction of } \\
\text { labelled } \mathrm{N} \\
\text { present at } \\
\text { budbreak }(\%)\end{array}$} \\
\hline & \begin{tabular}{|c|}
${ }^{15} \mathrm{~N}$ lost \\
between harvest \\
and leaf-fall \\
$(\%)$
\end{tabular} & $\begin{array}{c}{ }^{15} \mathrm{~N} \text { lost } \\
\text { between } \\
\text { harvest and } \\
\text { pruning (\%) }\end{array}$ & \\
\hline $\begin{array}{l}\text { End of bloom to end } \\
\text { of rapid shoot growth } \\
\text { End of rapid shoot } \\
\text { growth to véraison } \\
\text { Post harvest }\end{array}$ & $\begin{array}{c}38,7 \\
0\end{array}$ & $\begin{array}{l}57,8 \\
19,9\end{array}$ & $\begin{array}{r}57 \\
5\end{array}$ \\
\hline
\end{tabular}

The amount of $\mathrm{N}$ which migrated from the leaves in the case of the labelled pool accumulated during spring $(37,9 \%)$, was almost identical with the amount found for the "summer" pool $(38,7 \%)$. These amounts are lower than the average figure of $50 \%$ found for other deciduous crops like peaches (Stassen et al., 1981a) and apples (Taylor \& Van Ende, 1969). In the case of $\mathrm{N}$ absorbed during the post harvest period, no $\mathrm{N}$ migrated from the leaves back to the permanent structure. This was probably due to the fact that a large fraction of the post harvest $\mathrm{N}$ was directly incorporated into the permanent structure. In the case of the shoots, a much smaller fraction of the "spring $N$ " $(31,0 \%)$ migrated back to the permanent structure than was the case for "summer N" (57,8\%). A faster efflux of late absorbed $\mathrm{N}$ has also been found for wheat (Yoneyama, 1983). The fact that $\mathrm{N}$ migrated from the one-year-old shoots (pruning wood) to the permanent structure during dormancy, has received little previous attention, but similar indications were found for peaches (Stassen et al., 1981a), and may be due to the fact that roots have the ability to maintain activity at lower temperatures than the above-ground plant can (Tromp, 1983) and may therefore have a strong competitive ability for nutrients during the dormant stage, resulting in an efflux of $\mathrm{N}$ from the shoots. The total amount of $\mathrm{N}$ which migrated from leaves and shoots to the permanent structure constituted a large fraction of the $\mathrm{N}$ reserves present at budbreak in the cases of "spring N" and "summer N" (61\% and $57 \%$ respectively), while the contribution was negligible in the case of "autumn $N$ " $(5 \%)$.

The nitrogen contents of the bunches and the vegetative parts of the two cultivars used in the field trials (Chenin blanc/Jacquez for the sandy loam soil and Bukettraube/Ramsey for the sandy soil) are compared in Table 4 . The Chenin blanc required relatively less $\mathrm{N}$ in the bunches than was the case for Bukettraube, but more $\mathrm{N}$ was lost in the leaves of Chenin blanc. This indicated that the Chenin blanc vines utilised $\mathrm{N}$ less efficiently, probably on account of being considerably older than the Bukettraube vines. However, the total amounts of $\mathrm{N}$ utilised per vine were reasonably similar for the two cultivars, justifying an assumption that root uptake must have been nearly identical for the two cultivars.

TABLE 4

Comparison of the nitrogen utilised by vines from two vineyards ( $\mathrm{mg}$ per vine) $)^{(a)}$

\begin{tabular}{l|c|c}
\hline \multicolumn{1}{c|}{ Organ } & Chenin blanc/Jacquez & Bukettraube/Ramsey \\
\hline $\begin{array}{l}\text { Bunches at harvest } \\
\text { Leaves at end of }\end{array}$ & $4200 \pm 910$ & $5310 \pm 1080$ \\
leaf-fall & $4810 \pm 630$ & $3310 \pm 520$ \\
Shoots at pruning & $2860 \pm 410$ & $2560 \pm 320$ \\
Total & $11870 \pm 1700$ & $11000 \pm 1700$ \\
\hline
\end{tabular}

(a) Average of eight vines

The atom \% excesses of ${ }^{15} \mathrm{~N}$ found in the leaves of vines at various sampling dates, following spring and autumn application of ${ }^{15} \mathrm{~N}$, are shown in Table 5.

In the spring application a considerable amount of ${ }^{15} \mathrm{~N}$ was found in the leaves of vines on the sandy soil at the end of bloom, while only a small concentration was 
TABLE 5

Presence of ${ }^{15} \mathrm{~N}^{(\mathrm{a})}$ in leaf blades of grape-vines as affected by two soil types and time of application (atom \% excess $\left.{ }^{15} \mathrm{~N}\right)^{(\mathrm{b})}$

\begin{tabular}{l|c|c|c|c}
\hline \multirow{2}{*}{$\begin{array}{c}\text { Phenological stage at } \\
\text { time of sampling }\end{array}$} & \multicolumn{2}{|c|}{ Spring application ${ }^{(\mathrm{c})}$} & \multicolumn{2}{c}{ Autumn application ${ }^{(\mathrm{d})}$} \\
\cline { 2 - 5 } & $\begin{array}{c}\text { Glenrosa } \\
(20 \% \text { clay })\end{array}$ & $\begin{array}{c}\text { Kroonstad } \\
(8 \% \text { clay })\end{array}$ & $\begin{array}{c}\text { Glenrosa } \\
(20 \% \text { clay })\end{array}$ & $\begin{array}{c}\text { Kroonstad } \\
(8 \% \text { clay })\end{array}$ \\
\hline Two weeks after end of bloom & 0,036 & 0,416 & - & - \\
Harvest & 0,083 & 0,450 & - & -167 \\
End of leaf-fall & 0,071 & 0,296 & 0,013 & 0,167 \\
2nd Season & 0,057 & 0,043 & 0,118 & 0,207 \\
End of bloom & &
\end{tabular}

(a) $702 \mathrm{mg}$ of ${ }^{15} \mathrm{~N}$ enriched $\mathrm{KNO}_{3}\left(97\right.$ atom $\%$ excess $\left.{ }^{15} \mathrm{~N}\right)$ applied to each vine

(b) Average of three vines

(c) Application on 7th October, 5 weeks before bloom

(d) Application on 10th March, 13 weeks before end of leaf-fall

present in the leaves of vines on the sandy loam soil. This sampling was done only 7 weeks after application of the labelled $\mathrm{N}$ and it is possible that applied $\mathrm{N}$ had not yet reached the root zone in the case of the sandy loam or that it was misplaced in relation to the roots. On the other hand, with this soil containing more than twice as much $\mathrm{OM}$ as the sand, it can also be assumed that the mineralised $\mathrm{N}$ would be twice as high and the applied $\mathrm{N}$ would therefore be diluted to a much larger extent. The ${ }^{15} \mathrm{~N}$ concentration in the leaves from vines on the sandy loam increased twofold up to harvest, while that of leaves from vines on the sand increased only marginally but was still five times higher than the former. The ${ }^{15} \mathrm{~N}$ concentrations in the leaf blades decreased, in both cases, between harvest and the end of leaf-fall, pointing to the migration of $\mathrm{N}$ from the leaves. At the end of bloom in the second season leaves from vines on the sandy loam showed a slightly higher ${ }^{15} \mathrm{~N}$ concentration than leaves from vines on the sand. This implies that the ${ }^{15} \mathrm{~N}$ applied to the sand must have been nearly depleted by this time, while the sandy loam still contained a fair amount of residual ${ }^{15} \mathrm{~N}$.

In the case of ${ }^{15} \mathrm{~N}$ which was applied during autumn, the leaves of vines from the sandy loam soil contained only a small amount of ${ }^{15} \mathrm{~N}$ at the end of leaf-fall while a fairly high concentration $\left(0,167\right.$ atom $\%$ excess $\left.{ }^{15} \mathrm{~N}\right)$ was found in leaves from vines on the sandy soil. At the end of bloom in the next season however, the concentrations were nearer to each other and "autumn N" was obviously still being freely utilised on both soils. Leaching during winter could therefore not have occurred to a very large extent, even on the lighter soil. It is possible for part of the mineral $\mathrm{N}$ to have been utilised by the cover crop (rye) during winter, thus being protected against leaching. The cover crop was killed with a herbicide just before budbreak, i.e. at the end of the period during which heavy rainfall normally occurs. The labelled $\mathrm{N}$ in the straw mulch could then again become available through mineralisation. In an investigation with spring wheat, Feigenbaum, Seligman \& Benjamin (1984) found that during a relatively dry season a large amount of residual mineral $\mathrm{N}$ may remain in the soil to be utilised in subsequent years.

The utilisation of ${ }^{15} \mathrm{~N}$ enriched $\mathrm{KNO}_{3}$ by the grapevine as affected by two soil types and time of application is shown in absolute terms ( $\mathrm{mg}{ }^{15} \mathrm{~N}$ excess per vine) in Table 6. All data in this Table has been determined quantitatively except for the contribution of shoots in the second season which was calculated as shown, and that of the permanent structure which was calculated as follows: It was arbitrarily accepted that a negligible amount of ${ }^{15} \mathrm{~N}$ would have been absorbed from autumn onwards by vines on the sandy (Kroonstad) soil labelled during spring. The amount of ${ }^{15} \mathrm{~N}$ present in the permanent structure was thus estimated to constitute $22 \%$ of the annual total, i.e. the average amount found in the permanent structure, after one year, for $\mathrm{N}$ absorbed during spring and summer (Figure 1). For all other treatments the amount of labelled $\mathrm{N}$ in the permanent structure, was estimated at $28 \%$ of the annual total, i.e. the average fraction retained during a full season (Table 1). For the spring applications, the total amount of ${ }^{15} \mathrm{~N}$ recovered in the vines after one season, was $80 \%$ higher for the sandy soil than for the sandy loam. This was probably due to a larger reserve of naturally occurring mineral $\mathrm{N}$ in the case of the sandy loam, resulting in a larger dilution of applied fertiliser. Considering that vines on the sandy loam utilised only $30 \%$ of applied fertiliser during the first season after application in comparison to nearly $50 \%$ on the sandy soil, vines on the sandy loam can hardly be expected to react significantly to applied $\mathrm{N}$ fertilisers. In a long term fertiliser trial on this specific soil, very little response to $\mathrm{N}$ applications was actually found (W.J. Conradie \& D. Saayman, 1986, unpublished data). However, the amounts of labelled $\mathrm{N}$ recovered in this experiment were still considerably higher than the $2 \%$ to $25 \%$ found for apples under different cultivation practices (Atkinson et al., 1978). The amounts of labelled $\mathrm{N}$ recovered in the case of the autumn treatments were virtually identical with those of the spring treatments. Absorption of ${ }^{15} \mathrm{~N}$ therefore appeared to be equally or more effective in autumn and spring than in mid-summer. This is in contrast to the results obtained for apples in the Northern Hemisphere (Atkinson et al., 1978) and stresses the importance of autumn fertilisation under the climatic conditions of the Western Cape, where vines remain active for several months after harvest.

\section{CONCLUSIONS}

As was found for other deciduous crops, the grapevine relies on reserve $\mathrm{N}$ during the stage from budbreak to the end of bloom. During this period root uptake appears to be limited and $\mathrm{N}$ demand by the new growth 
TABLE 6

Presence of ${ }^{15} \mathrm{~N}^{(\mathrm{a})}$ in organs of grape-vines as affected by two soil types and time of application $\left(\mathrm{mg}{ }^{15} \mathrm{~N} \text { excess per organ }\right)^{(\mathrm{b})}$

\begin{tabular}{|c|c|c|c|c|}
\hline \multirow{2}{*}{$\begin{array}{l}\text { Organ and time of } \\
\text { sampling }\end{array}$} & \multicolumn{2}{|c|}{ Spring application } & \multicolumn{2}{|c|}{ Autumn application } \\
\hline & $\begin{array}{c}\text { Glenrosa } \\
(20 \% \text { clay })\end{array}$ & $\begin{array}{c}\text { Kroonstad } \\
\text { (8\% clay) }\end{array}$ & $\begin{array}{c}\text { Glenrosa } \\
(20 \% \text { clay })\end{array}$ & $\begin{array}{c}\text { Kroonstad } \\
(8 \% \text { clay })\end{array}$ \\
\hline $\begin{array}{l}\text { Bunches at harvest } \\
\text { Leaves at end of leaf-fall } \\
\text { Shoots at pruning }\end{array}$ & $\begin{array}{l}4,3 \pm 1,0 \\
4,4 \pm 0,8 \\
2,4 \pm 0,4\end{array}$ & $\begin{array}{r}19,8 \pm 3,8 \\
8,9 \pm 1,1 \\
4,8 \pm 0,7 \\
\end{array}$ & $\begin{array}{l}- \\
0,7 \pm 0,2 \\
0,3 \pm 0,1\end{array}$ & $\begin{array}{l}- \\
5,4 \pm 0,7 \\
4,9 \pm 0,8\end{array}$ \\
\hline $\begin{array}{l}\text { Sub Total } \\
\text { 2nd Season } \\
\text { Leaves at end of bloom } \\
\text { Shoots at end of bloom }{ }^{(c)} \\
\text { Bunches at } 5 \text { mm berry size } \\
\text { Permanent structure }\end{array}$ & $\begin{array}{l}11,1 \\
5,8 \pm 1,1 \\
2,6 \pm 0,3 \\
0,4 \pm 0,1 \\
7,7 \pm 1,5 \\
\end{array}$ & $\begin{array}{r}33,5 \\
3,4 \pm 0,5 \\
1,5 \pm 0,3 \\
0,4 \pm 0,1 \\
10,9 \pm 0,8\end{array}$ & $\begin{array}{r}1,0 \\
12,4 \pm 2,0 \\
5,5 \pm 0,6 \\
1,1 \pm 0,4 \\
7,8 \pm 1,1 \\
\end{array}$ & $\begin{array}{r}10,3 \\
16,1 \pm 2,1 \\
7,1 \pm 0,7 \\
3,1 \pm 0,6 \\
14,2 \pm 1,6 \\
\end{array}$ \\
\hline Total & 27,6 & 49,7 & 27,8 & 50,8 \\
\hline
\end{tabular}

(a) $702 \mathrm{mg}$ of ${ }^{15} \mathrm{~N}$ enriched $\mathrm{KNO}_{3}\left(97\right.$ atom \% excess ${ }^{15} \mathrm{~N}$ ) applied to each vine. This amounted to $100 \mathrm{mg}{ }^{15} \mathrm{~N}$ excess per vine

(b) Average of three vines

(c) According to the "spring" distribution of $\mathrm{N}$ shown in Figure 1, it was estimated that the shoots, at the end of bloom, contained $44,4 \%$ of the amount of ${ }^{15} \mathrm{~N}$ present in the leaves

(d) See text for calculation

could not be completely satisfied with newly absorbed $\mathrm{N}$. If this pattern also holds true for vines with low $\mathrm{N}$ reserves, it would be difficult to rectify a $\mathrm{N}$ deficiency during this period and heavy spring fertilisation could be wasteful, especially under conditions of low soil temperatures.

From the end of bloom to harvest the grape-vine is capable of absorbing large quantities of $\mathrm{N}$, but the major share of this newly acquired $\mathrm{N}$ is utilised by the bunches, leaves and shoots. Therefore, $\mathrm{N}$ reserves can only be marginally increased during this period. From budbreak until fruit maturity, nitrogen is utilised progressively less for vegetative growth and increasingly more by the fruit.

Nitrogen absorbed during the post harvest period has a large effect on the $\mathrm{N}$ reserves of the grape-vine and $\mathrm{N}$ fertilisation during this period should receive special at- tention. The $\mathrm{N}$ reserves of the grape-vine can be further increased if, during autumn, leaves are retained as long as possible.

The $\mathrm{N}$ supplying capacities of soils in the Western Cape should be further investigated. It would appear as if the mineralising capacity of soils containing only $1 \%$ organic matter may, in some cases, be sufficient to satisfy the $\mathrm{N}$ demand of the grape-vine. If the organic matter content can be sustained at this level, i.e. by means of a good stand of winter cover crop, which may include legumes, the addition of extra nitrogenous fertilisers may be unnecessary.

On soils with at least $8 \%$ clay, leaching of $\mathrm{N}$ does not appear to be excessive under Western Cape conditions. Residual fertiliser $\mathrm{N}$ from previous $\mathrm{N}$ applications should therefore be taken into account when estimating the $\mathrm{N}$ requirement of grape-vines.

\section{LITERATURE CITED}

ALEXANDER, D. McE., 1957. Seasonal changes in the nitrogen content of the Sultana vine. Aust. J. Agric. Res. 8, 162-178.

AMBERGER, A., 1983. Ways to control the availability, turnover and losses of mineral fertiliser $\mathrm{N}$ in soils. From: Efficient use of fertilisers in agriculture, 145-169. UNESCO, New York.

ATKINSON, D., JOHNSON, M.G., MATTAM, D. \& MERCER, E.R., 1978. The effect of orchard soil management on the uptake of nitrogen by established apple trees. J. Sci. Food Agric. 30, 129-135.

CONRADIE, W.J., 1980. Seasonal uptake of nutrients by Chenin blanc in sand culture: I. Nitrogen. S. Afr. J. Enol. Vitic. 1, 59-65.

CONRADIE, W.J., 1983. The uptake and distribution of ${ }^{15} \mathrm{~N}$ enriched nitrate by three rootstock cultivars grafted to Chenin blanc. S. Afr. J. Enol. Vitic. 4, 45-47.

CONRADIE, W.J., 1986. Nitrogen nutrition of the grape-vine (Vitis vinifera L.), PhD Thesis, Univ. of Stellenbosch.

FEIGENBAUM, S., SELIGMAN, N.G. \& BENJAMIN, R.W., 1984. Fate of Nitrogen-15 applied to spring wheat grown for three consecutive years in a semi-arid region. Soil Sci. Soc. Am. J. 48, 838-843.

HILL-COTTINGHAM, D.G. \& LLOYD-JONES, C.P., 1975. Nitrogen-15 in apple nutrition investigations. J. Sci. Food Agric. 26, 165-173.
KLIEWER, W.M. 1967. Annual cyclic changes in the concentration of free amino acids in grape-vines. Am. J. Enol. Vitic. 18, 126-137.

LAFON, J., COUILLAUD, P., GAY-BELLILE, F. \& LĖVY, J.F., 1965. Rythme de l'absorption minérale de la vigne au cours d'un cycle vegétatif. Vignes Vins 140, 17-21.

LEGAZ, F. \& MILLO, E. Primo, 1981. Dynamics of ${ }^{15} \mathrm{~N}$ labelled nitrogen nutrients in 'Valencia' orange trees. Proc. Int. Soc. Citriculture 2, 575-582.

MACVICAR, C.N. et al., 1977. Soil classification - a binomal system for South Africa. Dept. Agriculture, Pretoria.

MAROCKE, R., BALTHAZARD, J. \& HUGLIN, P., 1977. Données concernant les exportations en éléments fertilisants de la vigne et un essai de fumure. Proc. Int. Symp. on the quality of the vintage, 14-21 Feb. 1977, Cape town, 397-401.

MEYER, J.H., WOOD, R.A., McINTYRE, R.K. \& LEIBBRANDT, N.B., 1983. Classifying soils of the South African sugar industry on the basis of their nitrogen mineralising capacities and organic matter contents. SASTA Proc. 57, 1-8.

MÜLLER, K., 1982. Der pflanzenverfügbare Stickstoff in Weinbergsböden und die jahrliche N-Düngung. Dt. Weinbau 37, 330-334. 
PATE, J.S., 1980. Transport and partitioning of nitrogenous solutes. Ann. Rev. Plant Physiol. 31, 313-340.

SAAYMAN, D., 1981. Wingerdvoeding. Uit: Wingerdbou in SuidAfrika, 343-383 (Eds: J. Burger \& J. Deist). V.O.R.I., 7600 Stellenbosch.

SCHAEFER. H., 1981. Der jarhreszeitliche Verlauf des Stoffwechsels der löslichen und unlöslichen Proteine in den verholzten Rebenorganen. Wein-Wiss. 36, 3-20.

SCHARPF, H.D. \& WEHRMANN, J., 1979. Beurteilung der Stickstoffversorgung von Obstanlagen mit Hilfe der Bodenanalyse auf Mineralstickstoff ( $\mathrm{N}_{\min }$-Method). Erwerbsobstbau 21, 6669.

STASSEN, P.J.C., DU PREEZ, M \& STADLER, J.D., 1983. Reserves in full-bearing peach trees. Macro-element reserves and their role in peach trees. Decid. Fruit Grow. 33, 200-206.

STASSEN, P.J.C., STINDT, H.W., STRYDOM, D.K. \& TERBLANCHE, J.H., 1981a. Seasonal changes in nitrogen fractions of young Kakamas peach trees. Agroplantae 13, 63-72.

STASSEN, P.J.C., TERBLANCHE, J.H. \& STRYDOM, D.K. 1981b. The effect of time and rate of nitrogen application on development and composition of peach trees. Agroplantae 13, 55-61.
TAYLOR, B.K. \& VAN DEN ENDE, B., 1969. The nitrogen nutrition of the peach tree: IV. Storage and mobilization of nitrogen in mature trees. Aust. J. agric. Res. 20, 869-881.

TITUS, J.S. \& KANG, S., 1982. Nitrogen metabolism, translocation and recycling in apple trees. In: Horticultural reviews, Vol. 4, 204-246. (Ed: J. Janick). A.V.I. Publishing, Westport, Conn.

TROMP, J., 1983. Nutrient reserves in roots of fruit trees, in particular carbohydrates and nitrogen. Plant and Soil 71, 401-413.

WEHRMANN, J., SCHARPF, H.C., BÖHMER, M. \& WOLLRING, J., 1982. Determination of nitrogen fertiliser requirements by nitrate analysis of the soil and of the plant. Proc. 9th Int. Plant Nutrition Colloquium, 702-709.

WEINBAUM, S.A., MERWIN, M.L. \& MURAOKA, T.T., 1978. Seasonal variation in nitrate uptake efficiency and distribution of absorbed nitrogen in non-bearing prune trees. J. Amer. Soc. Hort., Sci. 103, 516-519.

YONEYAMA, T., 1983. Distribution of nitrogen absorbed during different times of growth in the plant parts of wheat and contribution to the grain amino acids. Soil Sci. Plant Nutr. 29, 193-207. 